\title{
Journalistikkens rolle i netværkssamfundet
}

\section{AF MARK ØRSTEN}

I netværkssamfundet presser den stigende medialisering grænserne mellem medier, politik, økonomi og kultur. Dette sætter medierne i stadig mere direkte konkurrence med staten, det private erhvervsliv, interesseorganisationerne m.v. om definitionsmagten inden for de væsentligste sfærer af samfundet, hvilket illustreres af for eksempel Muhammed-krisen og dokumentarfilmen 'Den hemmelige krig'. Begge sager viser dog også, at med mediernes centrale placering i netværkssamfundet følger et øget fokus på, med hvilken legitimitet medierne udfører deres rolle. Dermed bliver det gamle spørgsmål om journalistikkens tilstræbte objektivitet et af de mest centrale i spørgsmålet om, hvilken rolle journalistikken kan eller skal spille i netværkssamfundet.

\section{Netværkssamfundet eller det informationelle samfund}

Brugen af begrebet 'netværkssamfundet' er lige så udbredt som det teoretiske værk bag, Castells trebindsværk om 'The rise of the network society', er diskuteret og udskældt (Se for eksempel Bondebjerg 2003). Når det er værd at holde fast i begrebet alligevel i en diskussion af journalistikkens rolle i det senmoderne samfund, skyldes det, at medier, informationsteknologier og informationsproduktion jo er centrale bestanddele af Castells teori om netværkssamfundet (Castells 2000, Hassan 2004).

Hvad er så 'netværkssamfundet'? Til det svarer Castells (2000: 
469) at, "networks constitute the new social morphology of our societies, and the diffusion of networking logic substantially modifies the operation and outcomes in processes of production, experience, power, and culture." Netværksorganisering er ikke i sig selv noget nyt, men når netværksstrukturen bliver særligt determinerende for netop vores samfundsperiode, skyldes det, at "for the first time, the introduction of new information/communication technologies allows for networks to keep their flexibility and adaptability." (Castells 2000: 470). Det, som med andre ord udgør netværkssamfundets skønhed, er, at netværk, via de moderne informations- og kommunikationsteknologier, er kommunikativt forbundne og at denne kommunikation er med til, at holde netværkene i konstant kontakt med hinanden, såvel som potentielt åbne for nye forbindelser til (alle) andre netværk (Bondebjerg 2003). Som eksempler på netværk nævnes alt fra børser og narkotikanetværk til EU, der betegnes som en netværksstat. Det er med andre ord klart, at netværk findes mange steder og på mange niveauer, og at det derfor altid vil være nødvendigt at tydeliggøre, på hvilket niveau man befinder sig, samt hvilket type af netværk man beskæftiger sig med. Det er også klart, at det er de nye informations- og kommunikationsteknologier, der er drivkraften i netværkssamfundet. Dette bliver endnu tydeligere, hvis man inddrager Castells begreb om 'det informationelle samfund'. Det informationelle samfund er industrisamfundets afløser, og er kendetegnet ved, at det ikke længere er industriel produktion, der driver samfundets økonomi og udvikling. Det, som i stedet driver samfundet fremad, er “(...) information generation, processing, and transmission" (Castells 2000: 21). Processer som samtidig i det nye informationelle samfund "become the fundamental sources of productivity and power (...)" (Ibid). Faktisk ses begrebet om det informationelle samfund som et overordnet begreb i forhold til netværkssamfundet, der mest betragtes som et 'lag' i det informationelle samfund. Et lag, der er kendetegnet ved sin netværksstruktur. Som Castells skriver: "the network society does not exhaust all the meaning of the informational society" (Ibid).

Skønt det i første omgang er internettet, der er i fokus hos Castells, og massemedierne, i det omfang de beskrives, hovedsage- 
ligt forstås som multinationale konglomerater drevet af ønsket om fleksibel produktion og maximalt udbytte (Jf. Hassan 2004), så er det åbenlyst, at også medier i mere jordnær forstand, som for eksempel nyhedsmedier, spiller en afgørende rolle i produktionen og distributionen af informationer, og dermed også bliver en del af den nye samfundsstruktur og magtomvæltning, som Castells fremhæver, at det informationelle samfunds kommen varsler. Og effekten af denne udvikling er massiv, ifølge Castells, og intet sted kommer dette tydeligere til udtryk end i den omfattende medialisering af politik, kultur og hverdagsliv, som vi har set finde sted de seneste år (Hassan 2004). Med medialisering forstås, at moderne politik og kultur i høj grad domineres af kommunikations- og massemedierne (Hassan 2004, Arnoldi 2004), og det i en sådan grad, at Lash (2002) provokerende har sagt, at der i dag ikke længere findes et politisk eller kulturelt ståsted, der kan siges at være 'udenfor' medierne. Netværkssamfundet/det informationelle samfund er derfor i allerhøjeste grad også et mediesamfund (Arnoldi 2004, Hassan 2004).

\section{Medialisering og synlighed}

At netværkssamfundet også er et mediesamfund, betyder, at begreber som politik og kultur forandres, men også at magt samt mulighederne og vilkårene for magtudøvelse forandres. Få har beskrevet netop denne del af samfundets udvikling bedre end englænderen John B. Thompson i bøgerne 'Medierne og moderniteten' (1995) og 'Den politiske skandale' (2002), hvis undertitel netop er 'Magt og synlighed i mediealderen'. Thompsons bøger handler således netop om, hvordan det senmoderne samfunds informations- og kommunikationsteknologier er med til radikalt at ændre på samfundets magtforhold. Især fokuserer Thompson på det, han kalder for 'den nye synlighed' (Thompson 1995, 2002, 2005). Begrebet dækker en historisk udvikling, hvor magten i form af den enevældige konge i det store hele var usynlig for størstedelen af befolkningen, så er dagens informations- og kommunikationsteknologier i vid udstrækning med til at synliggøre både magten og udøverne af magten. Hvor man før selv skulle være til stede ved hoffet for eksempel for at opleve magtudøvelsen på tæt 
hold, kan man i dag via medierne følge med i magtudøvelsen i ens eget land, såvel som i store dele af resten af verden. Dette gælder alt fra billeder af demonstrationer, valghandlingerne, kup og politiske taler til lækkede informationer på nettet. Som Thompson (2005: 31) konkluderer: "Thanks to the media (...) previously hidden practices and events (have) been given an entirely new status as public and indeed politically explosive events (...)".

Denne nye synlighed muliggøres af de nye informations- og kommunikationsteknologier, men synlighedens form bestemmes også af samme informations- og kommunikationsteknologiers formatkrav, organisationsformer, kommercielle vilkår og de muligheder for sammenkoblinger som de moderne medieplatforme tilbyder. Dette har, ifølge Thompson, følgende betydning for vores samfund i dag: Fordi der eksisterer stadig flere former for medieret kommunikation på stadig flere platforme, og fordi mange medieorganisationer er relativt uafhængige af statsmagten, så er mængden af informationer, der produceres og transmitteres større, og dermed mindre mulig at kontrollere i dag, end den var tidligere. Et stadigt voksende informations- og kommunikationsnetværk tilbyder stadig større mængder af symbolsk materiale til stadigt større antal af mediebrugere (Thompson 2005).

\section{Medierne og konkurrencen om den symbolske magt}

Effekten af den nye synlighed som medialiseringen af politik, kultur og økonomi forårsager, er et øget fokus på det, som Thompson (2000) kalder for symbolsk magt og som andre kalder for medieskabt autoritet (Herbst 2003). Bag begge betegnelser gemmer der sig en videreudvikling af et fænomen som allerede blev fremhævet af kommunikationsforskerne Lazarsfeld og Merton i slutningen af 1940'erne, hvilket Herbst også fremhæver. Det, som Lazarsfeld og Merton (1948: 101-102) skrev, var følgende: "The mass media bestow prestige and enhance authority of individuals and groups by legitimizing their status." Og det er samme grundlæggende antagelse, der ligger bag begreberne om symbolsk magt og medieskabt autoritet.

Thompson (2000: 106) opererer med i alt fire former for magt: Politisk magt, økonomisk magt, tvangsmæssig magt og symbolsk 
magt. Politisk magt relateres hovedsageligt til staten, økonomisk magt til markedet og det private erhvervsliv, tvangsmæssig magt til politi og domstole, mens den symbolske magt omhandler (Thompson 2000: 107) „evnen til at gribe ind $i$ begivenheders gang, til at påvirke andres handlinger og forestillinger og endda til at skabe begivenheder ved hjoelp af frembringelse og overførsel af symbolske former. Mennesker, der udøver symbolsk magt, traekker på forskellige resurser som jeg løseligt vil beskrive som 'informations- og kommunikationsmidler'. Disse resurser indbefatter de tekniske midler til fiksering og udbredelse, de foerdigheder, kompetencer og vidensformer, der udnyttes i frembringelsen, udbredelsen og modtagelsen af information og symbolsk indhold." Desuden tilføjer Thompson også prestige, omdømme, anerkendelse og respekt til den symbolske magt, hvad enten man taler om institutioner eller personer. De fire magtformer ses ikke som indbyrdes uafhængige, men snarere som forskellige undergrupper af et samlet magtbegreb. Symbolsk magt er heller ikke en ny magtform. Typiske udøvere af symbolsk magt, set i et historisk perspektiv, vil således være de klassiske institutioner i samfundet; staten, domstolene, politiet, kirken, militæret, universiteterne osv. Men det er samtidig også klart, at samfundsudviklingen, med medialiseringen som særligt kendetegn, har givet medierne og deres symbolske magt en særlig position i nutidens samfund, og det er også af denne grund, at Thompson kæder den symbolske magt så tæt sammen med kontrol over/eller adgang til informations- og kommunikationsmidler. „Medierne bliver den hovedarena, hvor kampen om den symbolske magt udspiller sig. " (Thompson 2000: 115).

Medierne bliver på denne måde både udøvere af symbolsk magt såvel som det væsentligste middel til opnåelse af symbolsk magt. I vores medialiserede samfund betyder dette, at politikere, og andre som ønsker indflydelse, i stigende grad bliver afhængige af anvendelsen af symbolsk magt, fordi det er denne magt som i det medialiserede samfund, giver (størst) mulighed for at overtale og påvirke andre og dermed få afgørende indflydelse på begivenhedernes gang (Thompson 2000).

Samme tanker ligger bag Herbsts (2003) begreb 'medieskabt autoritet', der ses som en autoritetsform, der er særlig aktuel i en 
samfundsform, hvor medierne dominerer den offentlige debat. Medieskabt autoritet henviser således til den legitimitet, der kan opnås via citater, omtale, reklame, gæsteoptræden i aviser, blade, radio, net og tv. Thompson sidestiller symbolsk magt med andre former for magt, ligesom Herbst (2003) sammenkæder medieskabt autoritet med andre former for autoritet, som formuleret hos blandt andre Max Weber.

Couldry (2003) kritiserer imidlertid Thompsons definition af den symbolske magt for at være svag. Han mener, at man bør overveje den mulighed, at den symbolske magt ikke alene skal ses som en del af andre magtformer, men i stedet skal ses som den dominerende magtform, da den symbolske magt har mulighed for at udøve magt over andre magtformer. Den symbolske magt har således mulighed for at være trumfkort i for eksempel kampen om at vinde opstilling for et politisk parti. Her vil kandidater med symbolsk magt (f.eks. kendte) typiske blive foretrukket over andre typer af kandidater. Det samme gælder kampen om ordførerposter eller når en virksomhed skal ansætte en ny kommunikationsmedarbejder eller direktør. Den symbolske magt slår også igennem på metaniveau, som når for eksempel stadig flere institutioner delvis måles på deres optræden i medierne, når nyhedshistorier påvirker aktiekurser eller når nødhjælpsorganisationer optræder i tv-shows.

Resultatet af denne udvikling bliver, at når der inden for politik og kultur i stadig mindre grad findes et sted 'uden for' medierne, så bliver den symbolske magt, både den mennesker kan skabe sig og den medier kan udøve, central i forhold til at påvirke begivenhedernes gang. Couldry fremhæver så yderligere, at udviklingen har gjort, at medierne nu befinder sig i direkte konkurrence med statsmagten om den symbolske magt i samfundet: "Only the media, I suggest, are plausible rivals to the state”. (Couldry: 2003 672).

\section{Muhammed-krisen og 'Den hemmelige krig'}

At den symbolske magt, som medierne besidder, har fået øget betydning har vi på det seneste set i hvert fald to massive eksempler på i de danske medier; nemlig med Muhammed-krisen og dokumentarfilmen 'Den hemmelige krig'. Begge eksempler 
viser, hvor hård kampen om den symbolske magt kan være. Muhammed-krisen illustrerer således præcist mange af Castells pointer omkring kommunikation og information i netværkssamfundet. Den viser, hvordan produktionen af forskellige former for information kan skabe forbindelse til forskellige typer af magt, og hvordan den lynhurtige distribution af information kan skabe koblinger mellem netværk på tværs af tid og rum. Den illustrerer desuden også fint Castells pointe om, at det informationelle samfund, om end globalt, er omgivet af meget forskellige lokale, kulturelle kontekster og at dette kan have en væsentlig indflydelse på den kommunikation, som finder sted. Endelig illustrerer Muhammed-krisen også det potentielle kaos, som ligger immanent i de moderne kommunikations- og informationsteknologier og som udgør en voldsom styringsudfordring for samfundets traditionelle magtinstitutioner, så som staten.

DR's dokumentarfilm 'Den hemmelige krig' illustrerer til gengæld mere præcist Couldrys (2003) pointe om, at medierne ligger i direkte konkurrence med staten om den symbolske magt, herunder definitionsmagten inden for forskellige typer af problemstillinger. Hvor man med Muhammed-krisen kan sige, at Jyllands-Posten endte med at konkurrere med udenrigsministeriet og danske virksomheder om den symbolske repræsentation af Danmark i forhold til omverdenen, så konkurrerede DR med 'Den hemmelige krig' med staten og militæret om magten til, at definere den danske krigsindsats i Afghanistan. Når dette er muligt skyldes det, at krig i dag i meget høj grad er blevet medialiseret. Fra starten af en militær konflikt tænkes mediedækningen ind, ligesom medier bruges flittigt til at skabe opbakning til en krig (Kristensen og Ørsten 2006). Det vil med andre ord sige, at anvendelse af symbolsk magt, er instrumentel i forhold til moderne krig, men dette åbner selvfølgelig også op for en utrolig sårbarhed over for andre, evt. modstridende, former for symbolske præsentationer af en sådan krig.

Begge sager har desuden det til fælles, at de udløste diskussioner omkring troværdigheden af den journalistik, der lå til grund for de respektive historier. Kritikere stillede især spørgsmål ved mediernes politiske motiver til, at bringe de pågældende historier. Andre medier bidrog til debatten med analyser og udsagn, 
der ligeledes stillede spørgsmål ved den journalistiske troværdighed og især til den tilstræbte objektivitet. Især denne sidste del er værd, at hæfte sig ved. Thompson påpeger, at når politikere i så høj grad bruger medierne til at akkumulere symbolsk magt, så udsætter de sig selv for en synlighed, som samtidig gør dem uhyre sårbare. Sagt populært kan gode historier om en politiker og vellykket medieoptræden således tælle positivt på ens symbolske magtkonto, hvorimod en skandale eller anden dårlig/ uheldig medieoptræden hurtigt kan få kontoen til at gå mod nul. Den korte gennemgang af både Muhammed-krisen og 'Den hemmelige krig' viser imidlertid, at det ikke kun er politikere, der er åbne for den sårbarhed, som den nye synlighed påfører dem. Medierne selv er sårbare over for, at blive fremstillet i (andre) medier som for eksempel utroværdige. En medialiseret skandale, som er Thompsons fokus, kan lige så vel omhandle et andet medie som en politiker eller en direktør, og derfor bliver også medierne mere sårbare, fordi de med deres øgede synlighed også forsøger at samle symbolsk magt. En magtform som de i stigende grad er afhængige af for et overleve i en tilspidset konkurrencesituation. Det er således ikke kun politikere, der konkurrerer om at akkumulere symbolsk magt i medierne, medierne selv konkurrerer også med andre medier om, at akkumulere symbolsk magt via medierne.

\section{Kritikken af journalistikkens tilstræbte objektivitet i et konkurrenceperspektiv}

Medialiseringen af samfundet fører til, at også medierne selv må leve i skæret af Thompsons 'nye synlighed'. Dermed bliver mediernes egen magt også mere synlig, og dermed bliver medierne, ligesom politikere og andre medialiserede aktører, også mere sårbare overfor alt, der kan stille spørgsmålstegn ved deres symbolske magt forstået som „prestige, omdømme og anseelse“ Thompson (2000: 112). Der, hvor medierne, er mest sårbare over for angreb, er på spørgsmålet om deres troværdighed, og derfor ser vi også lige nu, i kølvandet på Muhammed-krisen og 'Den hemmelige krig', en øget debat omkring netop mediernes troværdighed. I traditionel journalistisk forstand har mediernes troværdig- 
hed altid været kædet sammen med begrebet om objektivitet eller tilstræbt objektivitet (Schudson 1978). Det vil sige journalistikkens ambition om at beskrive verden så tilstræbt objektivt som muligt. Objektivitetstanken, der stammer fra den amerikanske presses udviklingen i 1920'erne (Schudson 1978), og som slog igennem i Danmark efter Anden Verdenskrig (Meilby 1999), har altid været voldsomt debatteret både herhjemme og i USA, og begrebets anvendelighed i forhold til journalistikken af i dag er også blevet aflivet flere gange. Imidlertid er det tydeligt, at debatten fortsætter under flere forskellige navne. I public service-lovgivningen fremhæves kravene om saglighed og upartiskhed, begge betegnelser, der altid har stået i centrum for forsøgene på at definere, hvad objektivitet består af (jf. Westerståhl 1977). I den skrevne dagspresse er det værd at hæfte sig ved de etiske retningslinier som morgenaviserne har lagt ud på deres respektive hjemmesider. Jyllands-Posten skriver, at: „Journalistikken skal være så objektiv som muligt. Målet er at viderebringe den bedst opnåelige version af sandheden.“ (http://www1.jp.dk/info/journalistik.htm). Politikens etiske regler fremhæver, at: „Politikens journalistik skal være kritisk, saglig, korrekt og fair.“ (http:// politiken.dk/laesernesredaktoer/laesernesredaktoerfakta/article179 057.ece). Berlingske Tidende fremhæver, at: „Berlingske Tidende ser som en af sine fornemste opgaver at formidle åbent og nuanceret og uden bindinger af nogen art - hverken politisk, til virksomheder eller til interesseorganisationer." (http://www.berling ske.dk/forside/tema:fid=100100592). Kært paradigme har mange navne, men langt fra kravet om tilstræbt objektivitet er kravene til dagens journalistik i hvert fald ikke kommet. Da den seneste store debat om objektivitet og journalistik rasede i slutningen af 1960'erne og begyndelsen af 1970'erne, kom kritikken to steder fra. Inde fra medierne i form af for eksempel 'new journalism' og fra social- og samfundsvidenskaberne. Hvis vi lader den medieinterne kritik ligge, og koncentrerer os om den videnskabelige kritik, er Tuchmans artikel fra 1972 'Objektivitet som strategisk ritual' nok den meste kendte, og anerkendte, kritik af det journalistiske objektivitetsbegreb.

Tuchman har observeret journalisters arbejdsmetoder og konkluderer, at den journalistiske objektivitet i virkeligheden består 
af en række ritualer, så som indhentelsen af korrekte kildecitater, neutral præsentation m.m., som journalisten udfører i arbejdet med sin artikel og at ritualerne har til hensigt at beskytte journalisten og hans/hendes medie mod kritik udefra. Der er altså ikke tale om objektivitet i nogen endegyldig forstand, men blot om en operationel definition i form af forskellige procedurer og normer, der skal overholdes. Tuchman skriver endvidere, at en sådan rituel brug af begrebet objektivitet vil man også kunne finde hos andre professioner som; læger, advokater og videnskabsfolk.

Om det videnskabelige objektivitetsritual, der hovedsageligt går ud på at fremlægge sin metode, skriver Tuchman (1972: 677): "In this notion, objectivity simply means that a sociologist has described his procedures with such explicitness that others employing them on the same problem will come to the same conclusion." Meget tyder altså på, at mange professioner bruger postulatet om objektivitet som forsvar mod kritik udefra, konkluderer Tuchman, herunder journalister, læger, advokater og videnskabsmænd. Og kritikken af anvendelsen af objektivitet som strategisk ritual gælder således $i k k e$ journalistikken alene, men samtlige af de nævnte professioner.

Når det sjældent er denne del af Tuchmans tekst, der fremhæves, men i stedet hendes kritik af journalistikken skyldes det til dels, at det først er sidst i artiklen, at journalistikkens brug af objektivitet som strategisk ritual relateres til andre professioners brug af samme, dels at Tuchmans tekst er præget af klare normative forestillinger om især forskellen på videnskabsmænd og journalister. "The social scientist is a 'thinker'; the newsman a 'man of action. That is, the social scientist may engage in reflexive epistemological examination, the newsman cannot." (Tuchman 1972: 662). Denne klare normative forestilling om videnskabsmandens rolle som 'refleksiv tænker', og dermed som hævet et niveau over journalisten, løber som en rød tråd gennem teksten og forklarer måske, hvorfor Tuchman i den sidste ende glider af på spørgsmålet om, hvorvidt den ene professions brug af objektivitet som ritual nu også er bedre/værre end den anden professions brug af objektivitet som ritual. Set i lyset af Couldrys (2003) tanker om, at medierne, og dermed journalistikken, konkurrerer med andre samfundsinstitutioner om magten til at beskrive og 
definere samfundet, kunne man også læse Tuchmans tekst, og kritik af journalistikken, som et resultat af konkurrencen mellem journalister og videnskabsfolk.

Skønt mediernes rolle i 1960'erne og 1970'erne ikke var så dominerende som i dag, var det netop i denne periode, at medierne for alvor begyndte at manifestere sig som samfundsinstitution, og dermed indgå i konkurrence, ikke alene med staten, men også med især samfunds- og humanvidenskaber om at definere og beskrive dagens samfund og dette samfunds mest presserende problemer. Læst i dette perspektiv kan man forstå nødvendigheden af at holde fast i videnskabsmanden som hævet over journalisten.

Ser man i imidlertid på moderne bøger om videnskabelig objektivitet står det dog klart, at objektivitet i nogen endegyldig forstand ikke er muligt, heller ikke for den tænkende, rationelle videnskabsmand: „Kan forskeren så ikke vore objektiv i sin samfundsvidenskabelige virksomhed? Svaret må helt klart voere nej. (...) Derimod kan man tilncermelsesvis opnå en objektivitet, hvis man med objektivitet mener, noget henad 'bevidsthed og åbenhed' eller 'mangesidighed'." (Andersen \& Gamdrup 1994: 34). Med andre ord arbejder både videnskabsmænd og journalister i retning af det tilstræbte eller tilnærmelsesvis objektive. Begge professioner bruger objektivitet rituelt og af samme årsager: for at sikre den bedste kvalitet $\mathrm{i}$ arbejdet og forsøge at forhindre udefra kommende angreb på professionen og dens arbejde.

\section{Diskussion}

I det medialiserede netværkssamfund konkurrerer medierne med andre samfundsinstitutioner om den symbolske magt. Dermed bliver mediernes egen rolle som magthaver også mere synlig, og som konsekvens af denne nye synlighed, bliver også medierne mere sårbare overfor medialiseret kritik og medialiserede enkelt-sager og skandaler. Kritikken rettes mod mediernes troværdighed og dermed i den sidste ende mod det journalistiske ideal om tilstræbt objektivitet - et ideal som stadig lever i bedste velgående hos medierne trods årelang kritik og debat. En analyse af netop kritikken af mediernes objektivitet i et konkurrenceperspektiv sandsynliggør dog, at medierne i deres søgen efter til- 
stræbt objektivitet ikke står hverken værre eller bedre end andre professioner, der ligeledes bruger forestillinger om objektivitet til at styre arbejdsgange og undgå udefra kommende kritik. Til disse andre professioner hører for eksempel videnskabsmænd og -kvinder.

Ser man udelukkende på kritikken af den journalistiske brug af tilstræbt objektivitet, er det tydeligt at denne kritik også er præget af rene normative forestillinger omkring journalisters evner. Journalister anses således ikke for at have hverken tid eller evner til dybere refleksion (Tuchman 1972), evner som ellers netop kendetegner videnskabsmanden. Til disse påstande kan man i 2007 fremhæve følgende. For det første, at journalistuddannelserne i Danmark, og i store dele af den vestlige verden, i de seneste år har gennemgået en klar akademisering. Formålet med denne akademisering er, at øge journalisters evner og muligheder for refleksion, både over eget arbejde og den større samfundsmæssige kontekst, som journalistikken indgår i. Et sideløbende formål er, at sørge for, at journaliststuderende får førstehåndserfaring med udførelsen af videnskabeligt arbejde og dermed også erfaring med de klassiske videnskabelige metoder. Sagt med Tuchmans ord handler moderne journalistuddannelser altså om at uddanne journalister, der ikke kun handler, men også tænker.

Et andet tegn på øget journalistisk refleksion er fremvæksten af den såkaldte 'meta-journalistik' (Kristensen \& Ørsten 2006), som flere studier har beskæftiget sig ned. Meta-journalistik er journalistik om journalistikkens egne vilkår. Et eksempel kan være krigsjournalistik (Kristensen \& Ørsten 2006) eller valgkampsjournalistik. I begge situationer arbejder stærke kræfter på at påvirke det journalistiske billede af begivenhedernes gang. Midlerne er alt fra trusler til spin og manipulation af information. Under sådanne tilspidsede tilstande handler meta-journalistikken netop om det pres, som journalisterne udsættes for, de tanker de gør sig om det, og de påvirkninger de mener, at presset kan have for deres øvrige dækning. Meta-journalistik er med andre ord journalistisk refleksion over de påvirkninger, som journalister oplever i deres forsøg på at dække bestemte typer af begivenheder, og meta-journalistik må således forstås som en advarsel til læserne om mulig manipulation samt som et forsøg på at øge troværdig- 
heden af den journalistiske tekst ved åbenlyst at diskutere problematiske sider af tekstens kontekst.

Hos Tuchman spiller det tidspres, som journalister arbejder under også ind og begrænser den journalistiske mulighed for refleksion. Til det skal, for det første nævnes, at de journalister Tuchman observerer, og som hun altså bygger sine hypoteser på, alle er journalister uden faste stofområder. Derfor spiller erfaring og for eksempel et godt kildenetværk heller ikke ind på Tuchmans analyse af tidspresset. For det andet er det klart, at meget har forandret sig siden Tuchman lavede sit studie. Ja, der er stadig et tidspres, men det varierer efter medietype og i visse tilfælde også fra journalist til journalist. Journalister, der står på god fod med en redaktør, eller af anden grund har høj status på en redaktion, kan ofte forhandle sig til andre typer af deadlines end en nyankommen praktikant. Desuden har metoder til dataindsamling samt mængden af tilgængeligt data også forandret sig kraftigt siden 1960'erne og 1970'erne, hvilket betyder at for eksempel internettet - alt andet lige - langt hurtigere vil kunne skaffe journalisten de fornødne oplysninger i dag frem for tidligere, hvor telefonen stadig var det bedste middel til informationsindsamling.

Endelig fremhæver Tuchman det faktum, at medierne er under pres, for at levere et produkt, en vare, som noget der i høj grad påvirker den journalistiske mulighed for refleksion. Dette er sandsynligvis endnu mere tydeligt herhjemme i dag end tidligere. Med den øgede konkurrence på mediemarkedet er det klart, at den enkelte journalist i dag mødes af et krav om en stadig stigende produktion på stadig mindre tid, hvilket både gratisaviser og 24-timers nyhedskanaler er klare eksempler på. Der er også eksempler på, at den øgede konkurrence har ført til en repolitisering af aviserne, hvor det enkelte medies politiske standpunkt er blevet stadig tydeligere fremhævet. Dette sker både for, at den enkelte avis i højere grad kan adskille sig fra konkurrenterne og fordi en øget målgruppeorientering hos medierne også har politiske konsekvenser for avisens henvendelsesformer (Schultz 2007). Dette fremgår blandt andet af debatten om Muhammedkrisen og 'Den hemmelige krig', hvor begge medier, DR og Jyllands-Posten, blev mødt med anklager om unødig politisering af et væsentligt samfundsemne. 
Svaret på spørgsmålet om journalistikkens rolle i netværkssamfundet eller det informationelle samfund bliver derfor dette: Medialiseringen af samfundet skubber til grænserne mellem medier, politik, kultur og økonomi. Dette har gjort medierne til den centrale kamparena i kampen om at opnå symbolsk magt samtidig med, at medialiseringen har øget synligheden af denne magtkamp og dens aktører. Medierne og journalistikken er dermed kommet i centrum i det informationelle samfund, ligesom medierne er et centralt symbol på netop det informationelle samfund, hvor samfundets produktivitet og magt i høj grad er koncentreret omkring indsamlingen, behandlingen og distributionen af informationer og viden. Både Muhammed-krisen og debatten om DR-dokumentarfilmen 'Den hemmelige krig', viser, hvor potentielt magtfuld og kaotisk nyhedsmediernes distribution af informationer kan være i det globale, informationelle samfund. Samtidig viser begge sager også, at spørgsmålet om mediernes troværdighed og upartiskhed er et uhyre centralt spørgsmål i det informationelle samfund. Nutidens medier stræber stadig efter en tilstræbt objektiv dækning af begivenheder, hvad enten medierne direkte henviser til idealet om objektivitet eller til afledte begreber som saglighed, upartiskhed eller korrekt og fair dækning. Og skønt netop mediernes og journalistikkens fremhævelse af den tilstræbte objektivitet har været stærkt omdiskuteret, har jeg i denne artikel forsøgt at redegøre for, at denne kritik også kan læses i et andet lys, nemlig som et led i kampen om den symbolske magt, en kamp som ikke alene kæmpes mellem medierne og samfundets politiske aktører og institutioner, som fremhævet af Thompson, men som også kæmpes mellem medierne og samfunds- og humanvidenskaberne. I dag kæmpes også i stigende grad med naturvidenskaberne. Dette gælder for eksempel definitionen af forskellige typer af risici (Ørsten et al. 2005). Denne analyse befrier ikke den journalistiske stræben efter en saglig, fair og upartisk dækning for problemer, men påpeger i stedet, at stræben efter en form for tilstræbt objektivitet i både videnskaben og journalistikken, skal ses som et både ritual og et ideal. Et ritual, som ikke alene, som det er tilfældet hos Tuchman, har til hensigt at beskytte journalistikken mod angreb udefra, men derimod også et ideal, hvis tilstedeværelse mulig- 
gør en refleksion over både ritualet, som det udføres, og idealet som det tilstræbes. Inden for organisationsforskningen fremhæves det, hvordan organisationer påvirkes af idealer, der skaber institutionelle rammer for, hvordan organisationer skal se ud og opføre sig, ikke mindst i forhold til at sikre sig legitimitet i forhold til det omkringliggende samfund (Ørsten 2004). Den tilstræbte objektivitet skal således ses som et journalistisk ideal, der fordrer en bestemt rituel, men også refleksiv, tilgang til det journalistiske arbejde med en historie. Grundet mediernes centrale placering i det informationelle samfund er behovet for dette ideal atter blevet skærpet i forhold til, at sikre medierne den fornødne symbolske magt og legitimitet til, at kunne udføre deres arbejde i stigende konkurrence med samfundets andre magtinstanser. Samtidig er der tegn på en øget journalistisk refleksion, via meta-journalistikken, omkring netop journalistikkens rolle i det informationelle samfund, problemerne omkring den tilstræbte objektivitet og de stadig flere påvirkningsforsøg, som medierne og journalisterne oplever, når de dækker forskellige typer af begivenheder. Med til historien hører dog også, at den øgede konkurrence presser de enkelte medier og journalister til en stadig øget produktion, en udvikling, der lige som Tuchman (1972) fremhævede, alt andet lige, må ses som en trussel mod mulighederne for et gennembrud for en mere refleksiv form for journalistik, især hvis konkurrencen leder til en tydelig repolitisering af medierne. Mediernes status i det informationelle samfund afhænger således i høj grad af mediernes troværdighed, og derfor vil den debat og kritik af politikeres forsøg på at påvirke medierne, og mediernes forsøg på at sætte sig på den symbolske magt, som vi ser i denne tid, sandsynligvis blive en af de væsentlige debatter om mediernes rolle i lang tid fremover. 


\section{REFEREN CER}

Andersen, Vilmer \& Gamdrup, Peter (1994). Om problemformulering og projektarbejde, pp. 33-42 i Heine Andersen (red). Videnskabsteori og metodelcere. Bind I Introduktion, Frederiksberg: Samfundslitteratur.

Arnoldi, Jacob (2005). Den offentlige ekspert, Frederiksberg: Samfundslitteratur.

Bondebjerg, Ib (red.) (2003). Netvaerksbegrebet og Netvarkssamfundet, København: Modinet.

Castells, Manuel (2000). The rise of the network society, Oxford \& Malden: Blackwell Publishers.

Couldry, Nick (2003). "Media meta-capital: Extending the range of Bourdieu's field theory", Theory and Society 32, pp. 653-677.

Hassan, Robert (2004). Media, Politics and The Network Society, Berkshire \& New York: Open University Press.

Herbst, Susan (2003). "Political authority in a mediated age", Theory and Society (32), pp. 481-503.

Kristensen, Nete Nørgaard \& Ørsten, Mark (2006): Krigen i medierne, medierne i krig. Frederiksberg: Samfundslitteratur.

Lash, Scott (2004). Critique of Information, London, Thousand Oaks \& New Delhi: Sage.

Lazarsfeld, Paul \& Merton, Robert (1948). "Mass Communication, Popular Taste and Organized Social Action” i Lyman Bryson (ed.). The Communication of Ideas, New York: Harper \& Brothers.

Meilby, Mogens (1999). Journalistikkens grundtrin, Århus: Forlaget Ajour. Schudson, Michael (1978). Discovering the News, USA: Basic Books, Inc.

Schultz, Ida (2007). „Velkommen til segmentpressen“, Fagpressen, nr. 1/ 07.

Thompson, John B. (2005). "The New Visibility”, Theory, Culture \& Society, vol. 22 (6), pp. 31-51.

Thompson, John B. (1995). Medierne og Moderniteten, København: Hans Reitzels forlag.

Thompson, John B. (2000). Den politiske skandale, København: Hans Reitzels forlag.

Tuchman, Gaye (1972). "Objectivity as Strategic Ritual: An Examination of Newsmen's Notions of Objectivity”, American Journal of Sociology, Vol. 77, No. 4, pp. 660-679.

Westerståhl, Jörgen (1977). „Objektiv nyhetsförmedling“, Statsvetenskaplig Tidsskrift 77/3. 
Ørsten, Mark (2004). Transnational politisk journalistik, Roskilde: Skriftserie for journalistik på RUC.

Ørsten et al (2005). Miljøet i medierne, Roskilde: Skrifteserie for journalistik på RUC. 